\title{
Modifikasi dan Uji Kinerja Implement Rotavator Untuk Mencacah Serasah dan Tunggul Tanaman Tebu (Saccharum officinarum L.) Untuk Ratoon
}

\author{
Modification and Performance Test of Rotavator Implementation for Chopping Trash and Arrears of Sugar Cane \\ (Saccharum officinarum L.) for Ratoon
}

\author{
Tubagus Irfan Khiari ${ }^{1 \star}$, Musthofa Lutfi ${ }^{1}$, Gunomo Djoyowasito ${ }^{1}$
}

${ }^{1}$ Keteknikan Pertanian, Fakultas Teknologi Pertanian, Universitas Brawijaya, Jl. Veteran Malang, 65145, Indonesia

*E-mail: irfankhiari19@gmail.com

Diterima: 9 Juni 2020; Disetujui: 26 Agustus 2020

\begin{abstract}
ABSTRAK
Tebu merupakan salah satu komoditi unggulan yang ada di Indonesia, industri perkebunan tebu di Indonesia memiliki luas 420,146 hektar. Penanganan serasah sisa panen tanaman tebu di Indonesia selama ini dilakukan dengan cara dibakar. Hal ini menimbulkan lebih banyak kerugian. Oleh karena itu dilakukan modifikasi untuk merubah bajak rotari menjadi trash mulcher untuk mencacah serasah tebu. Untuk mengetahui hasil kualitas dari pencacahannya dilakukan pengukuran berat panjang serasah, persentase hasil pencacahan, dan persentase perubahan ketinggian tumpukan. Dilakukan juga pengukuran kapasitas dan efisiensi lapang, konsumsi bahan bakar dan slip roda untuk menentukan kinerja implement. Hasil penelitian yang dilakukan menunjukkan hasil caahan berada pada kategori kualitas kurang baik dan perlakuan yang memunjukkan hasil paling baik adalah perlakuan dengan kecepatan maju traktor $4,13 \mathrm{~km} / \mathrm{jam}$. Pengujian analisi statis struktural yang meliputi deformasi total dan tegangan von mises dilakukan dengan menggunakan software ANSYS dengan material mild steel. Nilai total deformasi pada desain sebelum dan sesudah modifikasi adalah 0,494 mm dan 0,052 mm. Sementara nilai tegangan von mises pada desain sebelum dan setealah modifikasi didaptakan sebesar $416,78 \mathrm{MPa}$ dan 77.02 MPa.
\end{abstract}

Kata kunci: ANSYS; Rotavator; Serasah; Tebu; Tunggak; Trash Mulcher

\begin{abstract}
Sugar cane is one of the leading commodities in Indonesia, the sugar cane plantation industry in Indonesia has 420,146 hectares area. Handling of the residual of sugar cane crop harvest in Indonesia has been done by burning. This results in more losses. Therefore a modification was made to turn the rotary plow into a trash mulcher to chop sugar cane litter. To find out the results of the quality of the enumeration, weight measurements of litter length, percentage of enumeration results, and percentage change in pile height. Field capacity and efficiency measurements, fuel consumption and wheel slip are also measured to determine the implementation performance. The results of the study showed that the results of the process were in the poor quality category and the treatment that showed the best results was the treatment with tractor forward speed of $4.13 \mathrm{~km} /$ hour. Structural static analysis testing which includes total deformation and von mises stress was carried out using ANSYS software with mild steel material. The total value of deformation in the design before and after modification is $0.494 \mathrm{~mm}$ and $0.052 \mathrm{~mm}$. While the von mises stress value in the design before and after modification was 416.78 MPa and 77.02 MPa.
\end{abstract}

Keywords: ANSYS; Rotavator; Trash; Cane; Delinquency; Trash Mulcher

\section{PENDAHULUAN}

Gula merupakan salah satu komoditi unggulan dalam perekonomian Indonesia. Gula juga menjadi salah satu bahan pangan utama yang dikonsumsi oleh masyarakat. Berdasarkan data, rata-rata masyarakat Indonesia mengkonsumsi 5,212 ons gula per bulan (Anonim, 2017). Tebu merupakan tanaman penghasil gula utama. Lebih dari 100 negara yang memproduksi gula, 78\%-nya dihasilkan dari tebu yang tumbuh di daerah beriklim tropis dan subtropis. Produksi rata-rata tebu di dunia berkisar antara 65 ton per hektar, dan negara penghasil tabu terbesar adalah Mesir dengan produksi tebu sebesar 105 ton per hektar (Hakim, 2010). Industri perkebunan tebu di Indonesia memiliki luas 420,146 hektar, dimana 227,847 hektar dari tanah tersebut merupakan perkebunan rakyat, 123,750 hektar merupakan perkebunan besar swasta, dan 68,549 hektar merupakan perkebunan besar negara. Provinsi Jawa
Timur menjadi provinsi produsen tebu terbesar di Indonesia dengan luas lahan sebesar 201,900 hektar.

Untuk mempersiapkan proses replanting umumnya dilakukan pembakaran lahan untuk menghilangkan serasah tebu. Apabila dilakukan pembakaran maka serasah akan terbuang sia-sia oleh karena itu serasah perlu dicacah sehingga dapat dibenamkan Kembali kedalam tanah sebagai sumber bahan organik untuk tanah. Salah satu implemen pencacah serasah tebu yang sudah ada merupakan mulcher produksi Shandong Shifeng Group Co. Ltd. yang menjadi pembeda antara implemen yang sudah ada adalah jenis dan bentuk pisaunya yang nantinya akan menghasilkan cacahan yang berbeda (Sugandi et al., 2017).

Bajak dapat diartikan sebagai suatu proses manipulasi tanah secara matematis yang bertujuan untuk mendapatkan struktur tanah sesuai keinginan untuk meminimalkan erosi, menetapkan konfigurasi permukaan 
yang spesifik untuk proses penanaman dan irigasi. Bajak rotari secara umum digunakan dalam tiga operasi utama yaitu, pembajakan, pemotongan, dan pencampuran tanah (Jakasania, et al., 2017). Karena daya dari bajak rotary ditransmisikan secara langsung ke pisau bajak, maka nilai efisiensi transmisi dalam bajak rotary menjadi tinggi. Lebih dari itu keberadaan traksi negatif dalam bajak rotary menyebabkan daya traksi yang dibutuhkan menurun sehingga traktor yang lebih kecil dapat digunakan dengan bajak tersebut untuk persiapan lahan (Zareiforoush, et al., 2010). Meskipun terdapat berbagai tipe pisau yang umum diproduksi, namun biasanya pisau tipe $L$ yang banyak digunakan pada implement rotavator.

Pisau bajak rotary memiliki umur kerja selama 2400 jam (8 tahun) dengan penggunaan annanual selama 300 jam. Umumnya pisau perlu diganti setelah penggunaan selama 300 - 350 jam. Oleh karena itu diperlukan pengembangan desain dan analisisstatis untuk menaikkan lama umur kerja pisau rotari dan mengurangi biaya pertanian. Sehingga tujuan dilakukannya penelitian ini adalah untuk memodifikasi, menguji kinerja, dan menganalisis pisau rotary (Vegad et al., 2016).

\section{METODOLOGI}

Bahan yang digunakan dalam penelitian ini adalah serasah tebu varietas bululawang dan bahan bakar traktor. Alat yang digunakan antara lain adalah traktor roda 4 shandong shifeng, bajak rotary, stopwatch, Solidwork 2017 SP05, dan ANSYS R18.1. Untuk memenuhi tujuan dari penelitian ini, dilakukan pengamatan dan pengambilan data secara langsung dengan pengujian kinerja pisau yang meliputi pengujian kapasitas lapang teoritis dan efektif, efisiensi lapang, konsumsi bahan bakar, dan slip roda. pengujian dilakukan dengan tiga variasi kecepatan maju traktor yaitu, 2,08 km/jam; 3,14 km/jam; dan 6,55 km/jam. Pengujian struktural menggunakan software ANSYS R18.1 meliputi pengujian total deformasi dan tegangan von mises dari desain sebelum dan sesudah modifikasi.

Uji kinerja implement bajak rotary dilakukan dengan tahapan sebagai berikut:

a. Mendesain geometri pisau implement menggunakan solidwork 2017 SP05

b. Melakukan pengukuran parameter awal yang meliputi luas lahan, tinggi tumpukan serta kondisi awal serasah

c. Melakukan pengamatan parameter yang diukur:

- Rata rata berat panjang serasah tebu (cm) Untuk mendapatkan nilai rataan berat panjang serasah tebu dilakukan pengambilan sampel secara langsung dengan meteran dan timbangan.

- Presentase kualitas hasil cacahan

Dilakukan pengkategorian kualitas hasil cacahan berdasarkan panjang serasah sesuai dengan standard SNI 7850:2010

- Kapasitas lapang teoritis dan efektif Untuk mendapatkan nilai kapasitas lapang diperlukan pengukuran luas lahan, lebar implement, dan waktu yang dibutuhkan untuk menyelesaikan luasan tertentu

- Efisiensi lapang

Untuk mendapatkan nilai efisiensi lapang diperlukan pengukuran kapasitas lapang teoritis dan kapasitas lapang efektif.

- Konsumsi bahan bakar

Perhitungan konsumsi bahan bakar dilakukan untuk setiap variasi kecepatan maju traktor. Isi tangka bahan bakar traktor hingga penuh, setalah perlakuan tambahkan bahan bakar hingga penuh.
Penambahan yang dilakukan merupakan nilai konsumsi bahan bakar tersebut

- Slip roda

Nilai slip merupakan perbandingan jarak tempuh saat melakukan dan tidak melakukan kerja pada jumlah putaran roda yang sama.

d. Melakukan pengujian statis dengan ANSYS R18.1

Pengujian dilakukan dengan mesh jensi fine dan dengan jenis material mild steel. Parameter pengujian yang digunakan meliputi traktor $40 \mathrm{HP}$, kecepatan putaran pisau 540 RPM, nilai efisiensi traksi $(\eta t)$ dan koefisien reservasi traktor $(\eta r r)$ sebesar 0,85 dan 0,75 , nilai kecepatan peripheral sebesar $5,36 \mathrm{~m} / \mathrm{s}$, Dan diameter ring pisau sebesar $190 \mathrm{~mm}$. daya yang dimiliki traktor akan didistribusikan pada seluruh pisau yang ada, dimana pada penelitian ini digunakan 24 pisau yang setiap 3 pisaunya tersambung pada satu ring. Pisau yang didesain dengan solidwork diimport kedalam ANSYS untuk pengujian statis. Desain dan karakteristik material pisau yang telah dimodifikasi dapat dilihat pada Gambar 1 dan Tabel 1.

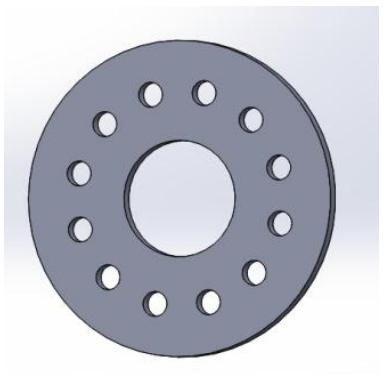

a

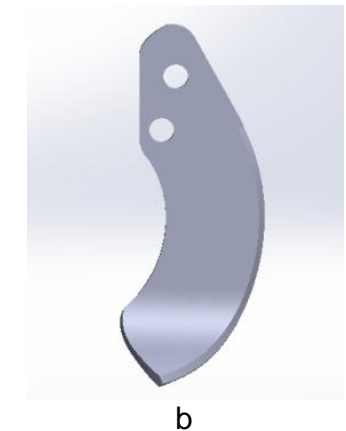

b
Gambar 1. Desain (a) Ring dan (b) Pisau

Tabel 1. Karakteristik Material

\begin{tabular}{|c|c|}
\hline Material & Mild steel \\
\hline Young's Module (Pa) & $2.10 \times e^{11}$ \\
\hline Poisson's ratio & 0.3 \\
\hline Comprehensive yield strength $(\mathrm{Pa})$ & $2.50 \times e^{8}$ \\
\hline Density $(\mathrm{t} / \mathrm{m} 3)$ & $7.87 \times e^{-9}$ \\
\hline Ultimate tensile strength $(\mathrm{Pa})$ & $4.40 \times e^{8}$ \\
\hline
\end{tabular}

Sumber: (Selvi, 2017)

Sebagai parameter utama dalam pengujian statis diperlukan nilai dari gaya peripheral pisau yang merupakan gaya yang diberikan tanah kepada pisau saat perlakuan. Nilai tersebut dapat dihitung menggunakan persamaan 1.

$\mathrm{K}_{\mathrm{o}}=\frac{75 \times \mathrm{BHP} \times \eta \mathrm{t} \times \eta \mathrm{rr} \times 9.81}{u}$

Dimana:

$\mathrm{K}_{\mathrm{o}} \quad=$ gaya peripheral $(\mathrm{N})$

$\mathrm{BHP}=$ penggerah utama $(\mathrm{HP})$

$\eta t \quad=$ efisiensi traksi,

$\eta r r=$ koefisien reservasi tenaga tractor

$\mathrm{u} \quad=$ kecepatan peripheral $(\mathrm{m} / \mathrm{s})$.

Setelah dilakukan perhitungan didapatkan bahwa nilai gaya yang diberikan oleh tanah pada pisau saat perlakuan adalah sebesar 3494,4 N. Nilai ini akan digunakan sebagai batasan kondisi force yang bertindak pada sumbu - $\mathrm{x}$, batasan kondisi lainnya adalah frictionless support pada bagian lubang baut. 


\section{HASIL DAN PEMBAHASAN}

\section{Spesifikasi Mulcher}

Mulcher yang digunakan merupakan mulcher hassil modifikasi milik PTPN X. mulcher tersebut memilki daya sebesar 40 HP dan kecepatan putaran sebesar $540 \mathrm{rpm}$. Mulcher yang digunakan memiliki lebar kerja sebpanjang $150 \mathrm{~cm}$.

\section{Rata Rata Berat Panjang Serasah Tebu}

Lahan yang digunakan sebagai tempat pengambilan data merupakan lahan tanaman tebu miliki pusat penelitian gula Djengkol yang berlokasi di Kecamatan Plosokidul, Kediri. Lahan yang digunakan memiliki luas sepanjang 50 meter dengan lebar 6 juring atau sekitar $255 \mathrm{~m}^{2}$. Hasil rata rata berat panjang serasah tebu dilakukan dengan pengukuran langsung menggunakan meteran dan timbangan. Berdasarkan data hasil penelitian didaptkan hasil nilai rata rata berat panjang serasah tebu untuk tiga variasi kecepatan maju traktor disajikan pada Gambar 3.

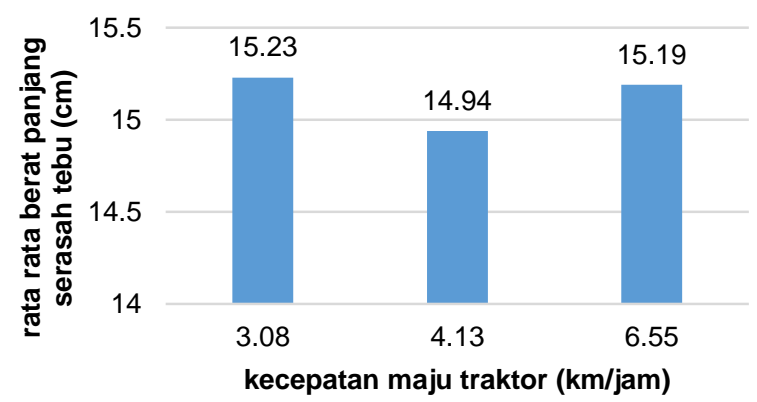

\section{Gambar 3. Rata Rata Berat Panjang Serasah Tebu}

Seperti yang dapat dilihat pada Gambar 3 diatas dapat dilihat bahwa didapatkan hasil yang tidak linear. Pada perlakuan dengan keceaptan $3,08 \mathrm{~km} / \mathrm{jam}$ didaptkan nilai rata-rata panjang serasah tebunya sepanjang $15,23 \mathrm{~cm}$, pada kecepatan $4,13 \mathrm{~km} / \mathrm{jam}$ sepanjang $14.94 \mathrm{~cm}$, dan pada kecepatan $6.55 \mathrm{~km} / \mathrm{jam}$ sepanjang $15,19 \mathrm{~cm}$. Hasil yang didapatkan dari ketiga kecepatan yang digunakan tidak jauh berbeda, ketiga hasil tersebut masuk dalam kategori hasil cacahan kurang baik menurut klasifikasi berat panjang serasah tebu.

\section{Presentase Hasil Cacahan}

Hasil persentase hasil pencacahan dapat digunakan untuk mendeteksi kualitas hasil cacahan secara detail dan juga untuk mengidentifikasi bagian bagian lahan yang tidak tercacah. Berdasarkan data hasil penelitian dan perhitungan yang sudah dilakukan, diperoleh nilai persentase hasil pencacahan seperti disajikan pada Gambar 4.

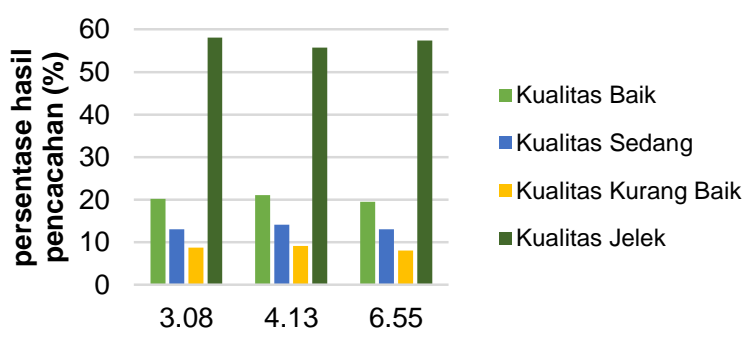

kecepatan maju traktor ( $\mathrm{km} / \mathrm{jam})$

Gambar 4. Persentase hasil cacahan

Berdasarkan Gambar 4 dapat dilihat bahwa pada pencacahan dengan kecepatan $3.08 \mathrm{~km} / \mathrm{jam}$ didapatkan persentase hasil pencacahan untuk kategori baik, sedang, kurang baik, dan jelek sesuai SNI 7850:2010 sebesar $20,17 \%, 13,07 \%, 8,7 \%$, dan $58,05 \%$, sedangkan pada pengujian dengan kecepatan $4,13 \mathrm{~km} / \mathrm{jam}$ didapatkan persentase hasil pencacahan sebesar $21,05 \%, 14,1 \%$, $9,16 \%$, dan $55,7 \%$ secara berurutan untuk kategori yang sama, dan untuk perlakuan dengan kecepatan $6,55 \mathrm{~km} / \mathrm{jam}$ didapatkan nilai persentase hasil pencacahan sebesar $19,53 \%, 13,08 \%, 8,04 \%$, dan $57,4 \%$ untuk kategori yang sama juga. Dari hasil tersebut didapatkan nilai rata rata persentase hasil pencacahan untuk kecepatan 3,08 $\mathrm{km} / \mathrm{jam}, 4,13 \mathrm{~km} / \mathrm{jam}$, dan 6,55 km/jam sebesar 24,89\%, $25 \%$, dan $24,51 \%$.

\section{Konsumsi Bahan Bakar}

Berdasarkan data yang diperoleh dari perlakuan. kecepatan $3.08 \mathrm{~km} / \mathrm{jam}, 4.13 \mathrm{~km} / \mathrm{jam}$, dan $6.55 \mathrm{~km} / \mathrm{jam}$ mengkonsumsi bahan bakar sebanyak $620 \mathrm{ml}, 140 \mathrm{ml}$, dan $490 \mathrm{ml}$ secara berurutan. Setelah dilakukan proses perhitungan didapatkan nilai konsumsi bahan bakar dalam liter/ jam untuk setiap kecepatannya dapat dilihat pada Gambar 5.

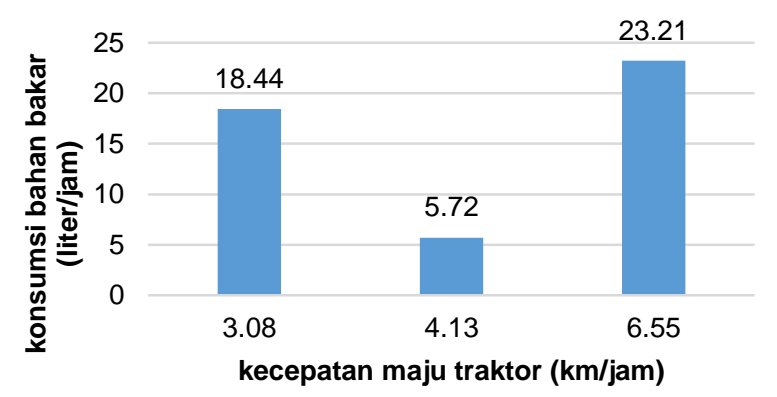

Gambar 5. Konsumsi bahan bakar

Berdasarkan data diatas dapat dilihat bahwa perlakuan dengan kecepatan maju traktor $4.13 \mathrm{~km} / \mathrm{jam}$ merupakan perlakuan yang mengkonsumsi bahan bakar paling sedikit, sementara kecepatan maju traktor $6.55 \mathrm{~km} / \mathrm{jam}$ mengkonsumsi bahan bakar per liter per jam terbanyak. Dapat dilihat pula bahwa terjadi kenaikan dari kecepatan $3.08 \mathrm{~km} / \mathrm{jam}$ dan $6.55 \mathrm{~km} / \mathrm{jam}$ hal ini menunjukkan adanya kenaikan konsumsi bahan bakar seiring pertambahan kecepatan. Hal ini sesuai dengan penelitian yang menyatakan bahwa seiring bertambahnya kecepatan maju traktor maka semakin banyak pula bahan bakar yang terkonsumsi (Adewoyin dan Ajav, 2017). Penelitian lain juga mendapatkan hasil yang sama dimana pada tiga perlakuan kecepatan maju traktor yang berbeda didapatkan kenaikan konsumsi bahan bakar seiring dengan bertambahnya kecepatan maju traktor (Asinyetogha, et al., 2019).

\section{Efisiensi Lapang}

Nilai efisiensi lapang merupakan nilai perbandingan antara kapasitas lapang teoritis dan efektif yang mana pada penelitian ini didapatkan nilai kapasitas lapang teoritis untuk tiga variasi kecepatan yang digunakan sebesar 0.53 ha/jam, 0.71 ha/jam, dan 1.12 ha/jam. Sementara nilai kapasitas lapang efektifnya didapatkan sebesar 0.44 ha/jam, 0.64 ha/jam, dan 0,91 ha/jam. Berdasarkan hasil perhitungan efisiensi lapang sesuai dengan Gambar 6 didapatkan bahwa pada kecepatan $3.08 \mathrm{~km} / \mathrm{jam}$ didapatkan efisiensi lapang sebesar $84.09 \%$, pada kecepatan 4.13 $\mathrm{km} / \mathrm{jam}$ didapatkan efisiensi sebesar $90.55 \%$ dan pada kecepatan $6.55 \mathrm{~km} / \mathrm{jam}$ didapatkan nilai efisiensi sebesar $81.37 \%$. Hal ini menunjukkan bahwa diantara ketiga perlakuan kecepatan yang digunakan, perlakuan yang paling efisien adalah dengan kecepatan $4.13 \mathrm{~km} / \mathrm{jam}$ dan 
yang paling tidak efisien adalah perlakukan dengan kecepatan $6.55 \mathrm{~km} / \mathrm{jam}$.

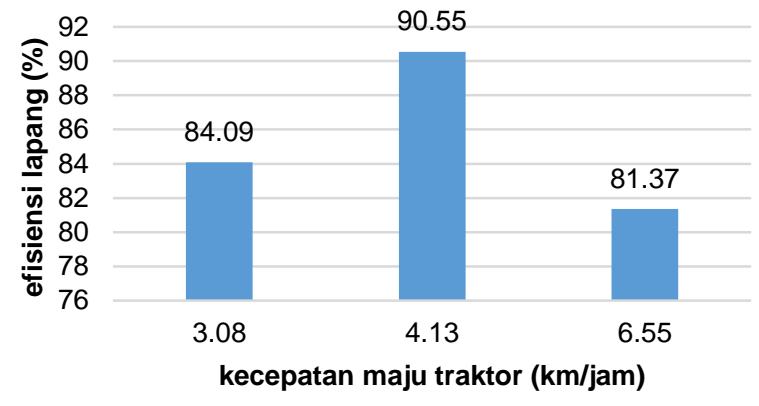

Gambar 6. Efisiensi Lapang

\section{Slip Roda}

Slip roda merupakan nilai yang didapatkan berdasarkan perbandingan dari jarak yang mampu ditempu traktor pada saat pengolahan di lahan dan saat tidak berkerja dalam 10 putaran roda. Sesuai dengan data hasil penelitian dan hasil perhitungan yang didapat maka didapatkan hasil penelitian slip seperti yang dapat dilihat pada Gambar 7 .

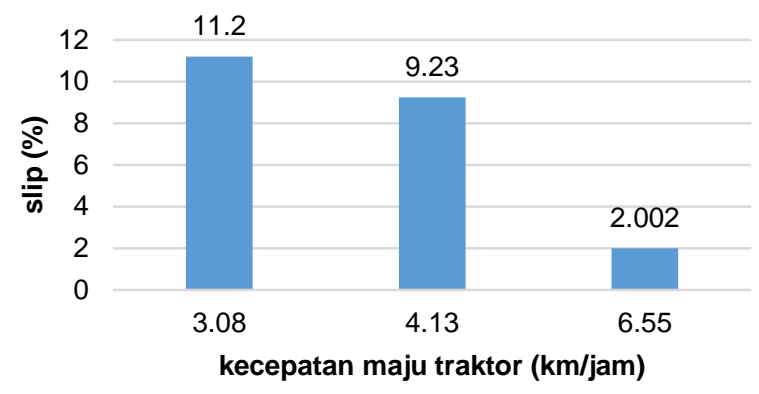

\section{Gambar 7. Slip Roda}

Pada Gambar 7 dapat dilihat bahwa nilai slip yang paling rendah didapatkan pada perlakuan dengan kecepatan 6,55 km/jam yaitu, sebesar $3.5 \%$, selanjutnya diikuti oleh kecepatan 4,13 km.jam dan 3,08 km/jam dengan nilai $9,23 \%$ dan $11,2 \%$. Beberapa faktor yang dapat mempengaruhi nilai slip ini adalah kecepatan, beban, serta kondisi dan vegetasi lahan tersebut yang digunakan. Pada penelitian lain dijelaskan bahwa, jika slip roda traktor yang berada dibawah $15 \%$ memiliki kemampuan traksi dan daya tarik roda yang masih efektif dalam menyalurkan daya mesin dalam bentuk traksi. Namun jika slip roda diatas $15 \%$ maka kemampuan traksi dan daya tarik traktor tersebut

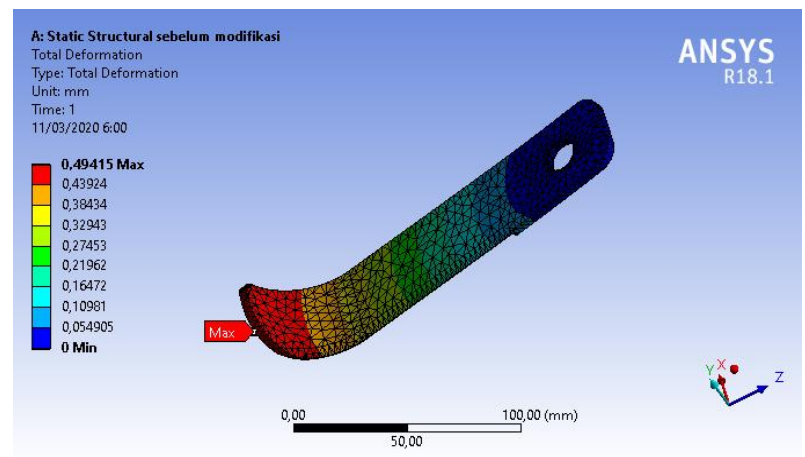

a kurang efektif dalam menyalurkan tenaga. Hal menunjukkan bahwa kemampuan traksi dan daya tarik roda masih efektif dalam menyalurkan daya mesin yang digunakan (Suastawa, et al., 2007; Ansar, 2011).

\section{Deformasi Total}

Berdasarkan hasil pengujian mengkunakan ANSYS R18.1 didapatkan hasil nilai total deformasi untuk desain pisau sebelum dan sesudah modifikasi sebesar $0,494 \mathrm{~mm}$ dan $0,052 \mathrm{~mm}$. hal ini menunjukkan bahwa terjadi penurunan hasil deformasi setelah dilakukan perubahan desain. Hasil analisis yang didapatkan dibagi menjadi beberapa kode warna, dimana kode warna tersebut melambangkan nilai dari total deformasi diseluruh bagian desain. Pada Gambar 8 dapat dilihat bahwa pada kedua desain nilai total deformasi yang tertinggi yang dilambangkan dengan warna merah berada pada bagian bawah dari pisau. Hal ini dapat diterima mengingat bagian tersebut yang terlabih dahulu mengenai tanah pada saat perlakuan. Sementara bagian atas dari kedua desain tersebut dilambangkan dengan warna biru yang berarti nilai deformasi pada area tersebut sangat rendah, hal tersebut dikarenakan pada bagian tersebut terdapat mur dan baut yang menyambungkan bagian tersebut kepada ring dan poros dari implement yang digunakan.

\section{Tegangan Von Mises}

Bila diamati pada Gambar 9 didapatkan bahwa nilai tegangan maksimal dari kedua desain yang dianalisa berada pada bagian lubang penghubung antara pisau dengan ring. Pada desain sebelum modifikasi didapatkan nilai tegangan maksimal sebesar $416,78 \mathrm{MPa}$ dan pada desain pisau setelah modifikasi didpatkan nilai sebesar $77,02 \mathrm{MPa}$. Hal ini menyatakan bahwa terjadi penurunan nilai tegangan von mises setelah dilakukan modifikasi desain. Pada penelitian lain ditemukan hal serupa dimana nilai tegangan maksimal berada di bagian lubang penghubung antara pisau dan ring, hal ini dikarenakan pada titik tersebut terdapat fix support atau sambungan mati yang mengakibatkan nilai tegangan naik ketika pisau berputar dan mengenai beban dari tanah (Selvi, 2017).

Nilai tegangan pada desain sebelum modifikasi berada diatas nilai comprehensive yield strengthnya yaitu sebesar $250 \mathrm{MPa}$ sehingga menghasilkan deformasi geometris yang berada pada domain palstis. Sementara itu nilai tegangan von mises pisau dengan diseain setelah modifikasi berada jauh dibawah nilai yield strengthnya sehinga menghasilkan nilai deformasi pada domain elastis yang berarti geometri tersebut akan kembali pada bentuk awal ketika beban yang diberikan hilang.

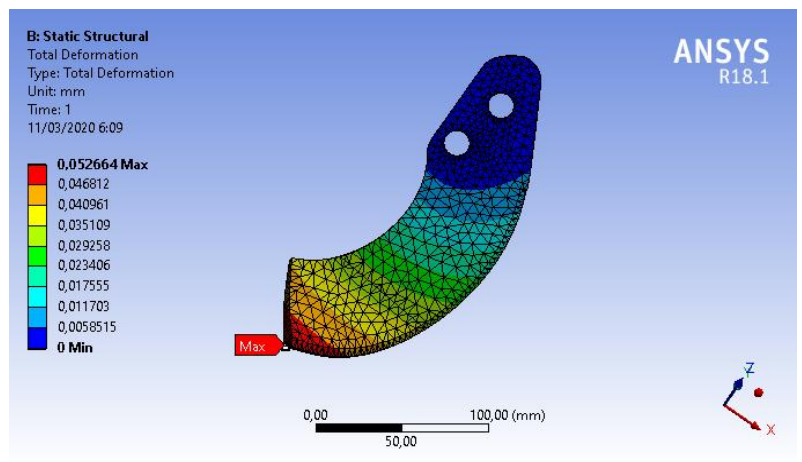

b

Gambar 8. Total Deformasi pada (a) Desain Sebelum Modifikasi (b) Desain Setelah Modifikasi 


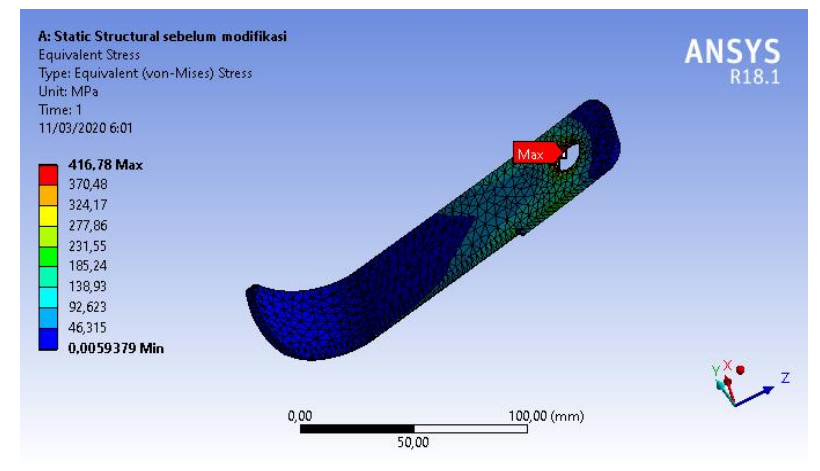

a

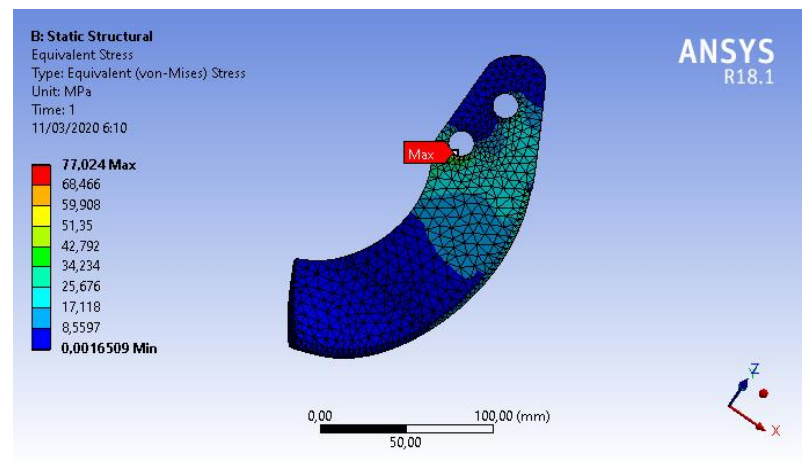

b

Gambar 9. Von Mises Stress pada (a) Desain Sebelum Modifikasi (b) Desain Setelah Modifikasi

\section{KESIMPULAN}

Hasil modifikasi yang dilakukan menghasilkan hasil pencacahan serasah tebu dengan panjang rata - rata 15 $\mathrm{cm}$ yang termasuk dalam kategori kurang baik. Uji kinerja yang dilakukan menyatakan bahwa efisiensi implemen yang digunakan banyak hilang akibat banyak melakukan belokan pada saat pengoperasian. Pengembagan dan pensimulasian desain menggunakan software komputer merupakan salah satu metode yang efektif untuk menyelesaikan permasalahan teknik yang kompleks dengan komponen yang terkontrol. Hasil yang didapatkan dengan melakukan simulasi tersebut cukup dapat diandalkan dalam segi mekanika kekuatan bahan. Pada penelitian ini perlakuan simulasi tersebut menghasilkan nilai total deformasi dan tegangan von mises pada desain sesudah modifikasi sebesar 0,052 $\mathrm{mm}$ dan $77,02 \mathrm{MPa}$ yang mana karena nilai tegangannya berada jauh dibawah yield strengthnya maka deformasi yang terjadi adalah deformasi plastis.

\section{DAFTAR PUSTAKA}

Adewoyin A.O., dan E. A. Ajav. (2013). Fuel Consumption Of Some Tractor Model For Ploughing Operation In The Sandy-Loam Soil Of Nigeria At Various Speeds And Ploughing Depths. Agric Eng Int CIGR J., vol. 15, no. 3, pp. 67-74.

Anonim. (2017). Distribusi Perdagangan Komoditas Gula Pasir Di Indonesia. Badan Pusat Statistik.

Ansar. (2011). Desain Dan Uji Performansi Roda Sirip Lengkung Traktor Tangan Untuk Pengolahan Tanah Di Lahan Kering. J. AGRITECH, vol. 31, no. 3, pp. 201-206.

Asinyetogha H.I., A. E. Raymond, dan O. N. Silas. (2019). Predicting tractor fuel consumption during ridging on a sandy loam soil in a humid tropical climate. J. Eng. Technol. Res., vol. 11, no. 3, pp. 29-40, Jun. 2019, doi: 10.5897/JETR2018.0658.

Hakim M. (2010). Potensi Sumber Daya Lahan Untuk Tanaman Tebu di Indonesia. J. Agrik., vol. 21, no. 1, pp. 5-12.

Jakasania R., A. Vadher, dan R. Kathiria. (2017). Performance Evaluation of Vertical Rotary Plough. J. Sci. Res. Reports, vol. 13, no. 6, pp. 1-7, Jan. 2017, doi: 10.9734/JSRR/2017/31757.

Suastawa I.P., P. Radite, and N. E. Sembiring. (2007). Kajian pengembangan alat industri. Departemen Perindustrian Republik Indonesia.

Selvi K., (2017). A New Blade Design of Rotary Tiller and Static Analysis Using Computer-Aided Tool.
INMATEH - Agric. Eng., vol. 53, no. 3, pp. 29-34.

Sugandi W.K., Suastawa I.N dan Wiyono, J. 2017. Kondisi lahan kebun tebu setelah panen dan karakteristik fisik dan mekanik serasah tebunya. Jurnal Teknik Pertanian Lampung., vol. 6, no. 3, pp. 133-140.

Vegad G., D. Yadav, dan J. G. (2016). Structural Analysis of Hatchet Type Rotavator Blade in CAD Software. in National Conference on Recent trends in Engineering, Management, Pharmacy, Architecture and Science.

Zareiforoush H., M. H. Komarizadeh, dan M. R. Alizadeh, (2010). Rotary Tiller Design Proportional to a Power Tiller using Specific Work Method (SWM). Nat. Sci., vol. 8, no. 9, pp. 40-45. 
TEKNOTAN, Vol. 14, No. 1, Agustus 2020

Halaman ini dikosongkan 